\title{
Debridement Applications of Bromelain: A Complex of Cysteine Proteases from Pineapple
}

\author{
Raquel Elisa da Silva López* \\ Oswaldo Cruz Foundation, Brazil
}

Submission: March 03, 2017; Published: June 21, 2017

*Corresponding author: Raquel Elisa da Silva López, Researcher, Chemistry of Natural Products Departament, Farmanguinhos, Oswaldo Cruz Foundation, 3465 Brasil Ave, Rio de Janeiro 21045-900, Brazil, Email: raquel.lopez@farfiocruz.br

Keywords: Bromelain; Therapeutic proteases; Clinical applications

\section{Introduction}

Plants are valuables sources of natural products, which are small molecules involved in ecological functions and referred as secondary metabolites, with important therapeutic properties. The isolation and purification of these metabolites were the main forces driving the birth of the pharmaceutical industry in the 19th century [1]. Nowadays, however, molecules from primary metabolism, such as proteins and peptides, are emerging as innovative therapeutic agents and are designated as biopharmaceuticals. Therapeutic enzymes are the major biopharmaceuticals and proteases or peptidases are the most class of enzymes used for clinical purposes. They cleave peptide bounds in peptides or proteins and are found in all living organisms, in different parts of a cell and can catalyze in a great diversity of conditions. Therefore, there are many types of proteases in the nature, since they represent about $2 \%$ of protein coding genes and plants are excellent sources of proteolytic enzymes with great activity and stability $[2,3]$.

Bromelain is a crude aqueous extract rich in cysteine proteases obtained from stem and fruit of Bromeliaceae family, of which pineapple, a common name of Ananas comosus (syns. A. sativus, Ananassa sativa, Bromelia ananas, B. comosa), is the most known specie. Besides, there are nonproteolytic components of bromelain, such as escharase, acid phosphatases, glycosidases, peroxidases, ribonucleases, cellulases, glycoproteins, carbohydrates, protease inhibitors and others organic and inorganic components. The pineapple tissues contain at least four glycosylated proteases with molar masses from 20 to $31 \mathrm{kDa}$ that belongs to papain superfamily: stem bromelain (EC 3.4.22.32), fruit bromelain (EC 3.4.22.33), ananain (EC 3.4.22.31) and comosain. These enzymes are responsible for high proteolytic activity of bromelain and they are showed expressive stability in high temperatures and in presence of many chemical compounds [4,5].

This extract has been employed commercially in many types of industries such as food, beverage, tenderization, cosmetic, textiles and pharmaceutical. It has been used as a medicinal plant in several native cultures and the medicinal propertiesof pineapple are attributed to bromelain, which has been chemically known since 1876. A wide range of therapeutic benefits and clinical include inhibition of platelet aggregation, sinusitis, surgical traumas, thrombo phlebitis, pyelonephritis, angina pectoris, bronchitis, enhance the absorption of drugs, relieves osteoarthritis, fibrinolytic, anti-edematous, anti-inflammatory, anti-cancer, anti-diarrhea, and wound healing by debridement [6] (Figure 1).

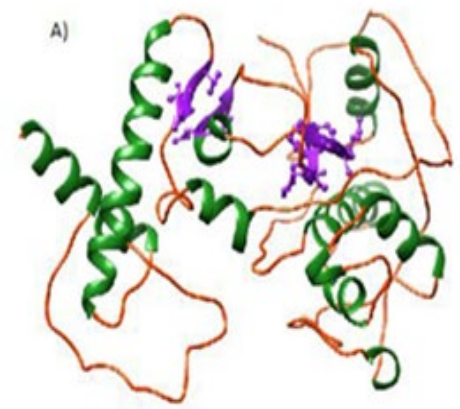

Figure 1: Structure of stem bromelain predicted by modeler. Tap et al. (2016)Int J App Eng Res 11: 6109-6111. 
Debridement is the procedure of removing dead tissues from the wound. The establishment of a healthy wound through suitable debridement of infected, senescent, and/or devitalized tissues is central to the progression of normal wound healing. It is an intricate biological process of repair, which typically progresses through four overlapping phases: hemostasis, inflammation, proliferation, and remodeling. The devitalized tissue can obstruct or stop wound healing and the purpose of debridement is to transform a chronic to an acute wound and to initiate the process of healing. The debridement methodology depends on the amount of necrotic tissue, the size and depth of the wound, the underlying disease, the comorbidity, as well as on the general condition of the patient. Besides, debridement significantly reduces bacterial burden. There are several types of debridement and the enzymatic employs proteases that degrade necrotic debris derived from cell breakdown and are involved in the regulation of cell maturation and multiplication; collagen synthesis and turnover; development and removal of the perivascular fibrin cuffs found in venous insufficiency and ulceration as well as the removal of dead tissues following inflammation. Many enzymes are currently commercially available and being promoted as alternatives to surgical wound debridement and bromelain is the most employed [6,7].

Proteases from bromelain, hydrolyze the fibrin clot deposited on the wound during the first phase of healing to avoid the bleeding. They also proteolysis collagen, elastin, laminin, fibronectin and other damaged components of extracellular matrix. This matrix digestion triggers the release of growth and angiogenic factors sequestered in matrix, as well as activation of bioactive chemokines and cytokines, and processing of cellcell and cell-matrix adhesion molecules [8]. So, bromelain promotes the suitable healing of wound. Topical formulation, as cream or gels, are the most employed to threat the different types of wounds. If applied as a cream (35\% bromelain in a lipid base), removes damaged tissue from wounds or second/third degree burns and can be beneficial for debridement of necrotic tissue and acceleration of healing. Burns are characterized by formation of an eschar, which is made up of burned and traumatized tissue, which also serves as a medium for bacterial growth and therefore a source of infection of the injury and to the neighbor undamaged tissues. Besides proteases, bromelain contains escharase that cleave glycosaminoglycan substrates and efficiently removes eschars. In enzymatic debridement studies carried out in porcine model, using bromelain-based agents, showed rapid removal of the necrotic layer of the dermis with preservation of healthy tissues. This process accelerated the recovery of blood perfusion, $\mathrm{pO}_{2}$ in wound tissue, controlled the expression of tumour necrosis factor- $\alpha$ (TNF- $\alpha$ ), which provide a chemotactic gradient for additional leukocytes to enhance the inflammatory process, and raised the expression of transforming growth factor-beta 1 (TGT- $\beta$ ), which stimulates cytokine secretion from macrophages and enhances fibroblast and smooth muscle cell chemotaxis, reprograming the wound microenvironment to promote effective tissue repair $[7,9]$.

Enzymatic debridement using bromelain is better than surgical debridement, since surgical incision is painful, nonselective and exposes the patients to the risk of repeated anaesthesia and significant bleeding. Patients who underwent bromelain had a significantly shorter time to complete debridement and considerably reduces morbidity and the mortality of severely burned patients. It permits early skin grafting and less problems of infection. Topical bromelain was reported to achieve complete debridement on experimental burns in rats in about 2 days, as compared with collagenase, which required about 10 days, with no side effects or damage to adjacent burned tissue. When topical bromelain was used for frostbite eschar removal, no debridement other than of superficial eschar layers was noted and, complete debridement was observed after only one to two brief applications with minimal side effects and no blood loss. Bromelain has also been found to improve gunshot wound healing, showing significant advantages over conventional surgical debridement by greatly simplifying the procedure involved [5,9]. A lyophilized, partially purified proteolytic protein mixture with increased specific enzymatic activity, derived from bromelain extracted from pineapple stems and bromelain-containing gel was very effective in debridement of deeply burned and both reduced the need for surgery. Burns are common injuries associated with significant morbidity and mortality, often leading to disfigurement and dysfunction due to scarring. In these cases bromelain debridement reduced the number of patients with burns who required an operative procedure, as well as the wound area grafted in those who did undergo skin grafting [10].

\section{Conclusion}

Bromelain is a plant extract which contains various components that might vary according to soil composition, climate conditions during plant growth, geographical location where the vegetal was grown, pineapple variety and the process of extraction. These factors might contribute to the variations of bromelain's pharmacological activities and the proteolytic activity has been shown to play an important part in its pharmacological activity. Since the discovery of bromelain, several studies have been undertaken to investigate the protease stability, purification, and potential applications and this mini review aimed to summarize only its application in wound debridement. Bromelain shows significant promise in medicine and healthcare, although its mode of action is not yet completely understood. This extract and their proteases are safe, nontoxic, successful type of therapeutic agents, and are being used worldwide for a number of diseases and conditions, especially for wound debridement due to the low cost, because bromelain is produced from a natural product by simple and easy methodology, high efficacy and celerity in healing of distinctive types wounds. 


\section{References}

1. Drews J (2000) Drug Discovery: A Historical Perspective. Science 287(5460): 1960-1964

2. Craik CS, Page MJ, Madison EL (2011) Proteases as therape utics. Biochem J 435: 1-16.

3. Gonçalves RN, Barbosa SDG, Silva-López RE (2016) Proteases from Canavalia ensiformis: active and thermostable enzymes with potential of application in biotechnology. Biotechnol Res Int 2016: 1-11.

4. Novaes LCL, Jozala AF, Lopes AM, Santos-Ebinuma VC, Mazzola PG, et al. (2016) Stability, purification, and applications of bromelain: a review. Biotechnol Prog 32: 5-13.

5. Krieger Y, Shoham Y, Bogdanov-Berezovsky A, Silberstein E, Sagi A, et al. (2016) Review of 30 years of research and development of an enzymatic debridement agent for burns. Harefuah 155: 281-285.
6. Pavan R, Jain S, Shraddha P, Kumar A (2012) Properties and therapeutic application of bromelain: a review. Biotechnol Res Int 2012: 976203.

7. Anghel EL, DeFazio MV, Barker JC, Janis JE, Attinger CE (2016) Current Concepts in Debridement: Science and Strategies. Plast Reconstr Surg 138: 82S-93S

8. Das U, Behera SS, Pramanik K (2017) Ethno-Herbal-Medico in Wound Repair: An Incisive Review. Phytother Res 31(4): 579-590.

9. Wu SY, Hu W, Zhang B, Liu S, Wang JM, et al. (2012) Bromelain ameliorates the wound microenvironment and improves the healing of firearm wounds. J Surg Res 176(2): 503-509.

10. Muhammad ZA, Ahmad T (2017) Therapeutic uses of pineapple extracted bromelain in surgical care - A review. J Pak Med Assoc 67(1): 121-125.

\section{Your next submission with Juniper Publishers will reach you the below assets}

- Quality Editorial service

- Swift Peer Review

- Reprints availability

- E-prints Service

- Manuscript Podcast for convenient understanding

- Global attainment for your research

- Manuscript accessibility in different formats

( Pdf, E-pub, Full Text, Audio)

- Unceasing customer service

Track the below URL for one-step submission https://juniperpublishers.com/online-submission.php 